\title{
DIREITO PENAL DO INIMIGO X DIREITO PENAL DO CIDADÃO
}

\section{Déa Carla Pereira Nery José Renato Oliva de Mattos Filho}

ISSUE DOI: $10.21207 / 1983.4225 .268$

\section{RESUMO}

O artigo analisa o Direito Penal do Inimigo em contraposto ao Direito Penal do Cidadão, ressaltando a necessidade do Estado não reconhecer o autor do fato delituoso como um inimigo que deve ser destruído, mas sim como um indivíduo que apresentou um comportamento que feriu a norma, contudo não perdeu sua condição de cidadão e seu direito de reintegrar-se à sociedade.

Palavras-Chave - Direito Penal do Inimigo. Direito Penal do Cidadão. Delinquente e reintegração na sociedade.

\section{INTRODUÇÃO}

O discurso atual do direito penal do inimigo renuncia as garantias materiais e processuais do direito penal da normalidade. Tais princípios e regras próprias do direito penal do inimigo estão impostos pelo significado das circunstâncias fáticas que caracterizam a atividade e a posição do inimigo frente à sociedade. Portanto, estariam configurados 
como instrumentos adequados ao fim de prevenção do perigo que representa o inimigo, que somente podem ser alcançados mediante seu vencimento ou sua eliminação na guerra desatada entre ele (o inimigo) e o Estado, através do seu isolamento. Enfim, para enfrentar os inimigos, recorre-se nas sociedades modernas aos regulamentos jurídico- penais com características que permitem identificá-las como típicas de um direito penal do inimigo.

Segundo Jakobs e Meliá, o Estado pode proceder de dois modos com os delinqüentes. Poderá vê-los como pessoas que delinqüem, ou seja, pessoas que tenham cometido um erro, ou indivíduos que devem ser impedidos de destruir o ordenamento jurídico, mediante coação. ${ }^{1}$

Nesse sentido, Gracia Martín afirma:

En realidad, este llamado Derecho penal del enemigo sería uno que se apartaría de los fines ordinarios del Derecho penal, es decir, de la reafirmación de ordenamiento jurídico o de la norma infringida conforme a la ideología de la llamada actualmente prevención general positiva, de la prevención general de intimidación y de la prevención especial rehabilitadora o de reinserción social. Se trataría más bien de una legislación de lucha o de guerra contra el enemigo cuyo único fin sería su exclusión e inocuización. El fin principal del Derecho penal del enemigo es la seguridad cognitiva. En él no se trata ya - como sucede en el Derecho penal general - de la conservación o mantenimiento del orden, sino de la producción en el entorno de condiciones soportables por medio de las cuales sean eliminados todos aquéllos que no ofrecen la garantía cognitiva mínima que es necesaria para poder ser tratados como personas. El Derecho penal del enemigo es la regulación jurídica de la exclusión de los enemigos, la cual se justifica en tanto en cuanto éstos son actualmente nopersonas, y conceptualmente hace pensar en una guerra cuyo alcance, limitado o total, depende de

1 JAKOBS, Gunther; CANCIO MELIÁ, Manuel. Direito penal do inimigo: noções e críticas. 4. ed. TraduçãoAndré Luís Callegari. Porto Alegre: Livraria do Advogado, 2009. p. 40. 
todo aquello que se teme de ellos. 'El derecho penal de enemigos optimiza la protección de bienes jurídicos, [mientras que] el Derecho penal de ciudadanos optimiza las esferas de libertad'. Mediante el Derecho penal del enemigo, el Estado ya no dialoga con ciudadanos para mantener la vigencia de la norma, sino que combate a sus enemigos, es decir, combate peligros, y, por ello, en él 'la pena se dirige hacia el aseguramiento frente a hechos futuros, no a la sanción de hechos cometidos'. $^{2}$

Segundo Gracia Martín, uma primeira manifestação do direito penal do inimigo está representada por alguns tipos penais, em que existe uma ampla antecipação da punibilidade a momentos em que os atos realizados somente têm caráter de preparatórios de atos futuros. Ou seja, condutas que consistem em ameaça permanente a princípios básicos da sociedade (falta de segurança), como condutas informadas e motivadas por pertencerem a uma organização que opera fora do Direito. Dessa forma, criminalizam-se comportamentos de mera colaboração com grupos e organizações terroristas, inclusive a apologia das infrações de terrorismo ou de seus autores.

A segunda característica do direito penal do inimigo, exposta pelo supra citado penalista, consiste na desproporcionalidade das penas, que teriam uma dupla manifestação. Desta forma, a criminalização de condutas no âmbito prévio não é acompanhada de redução da pena com respeito àquela fixada para os fatos consumados ou tentados, relacionados às aludidas condutas prévias. Vale dizer ainda que a circunstância do autor pertencer a uma organização é considerada para estabelecer agravações, consideradas, em princípio, desproporcionadas.

No cenário alemão, Jakobs reconhece também como uma manifestação típica do direito penal do inimigo o fato de que numerosas leis penais alemãs dos últimos anos se autodenominam abertas. São aquelas chamadas "leis de luta ou combate", que representam, segundo Jakobs, "um passo da legislação penal a uma legislação de combate".

${ }^{2}$ GRACIA MARTÍN, Luis. El horizonte del finalismo y el "derecho penal del inimigo". Valencia: Tirant lo Blanch, 2005. p. 106. 
Ademais, Gracia Martín, menciona ainda que outra forma de identificação do direito penal do inimigo é a considerável restrição de garantias e direitos processuais dos imputados. Afirma este autor:

Así, se pone ya en cuestión hasta la presunción de inocencia, por ser opuesta a la exigencia de veracidad en el procedimiento, se reducen considerablemente las exigencias de licitud y admisibilidad de la prueba, se introducen medidas amplias de intervención de las comunicaciones, de investigación secreta o clandestina, de incomunicación, se prescinde del - o se reinterpreta restrictivamente el - principio nemotenetur se ipsumaccusare, o, por citar sólo un exponente más, se amplián los plazos de detención policial, para el cumplimiento de "fines investigadores", así como los de prisión preventiva, y ya en el plano teórico doctrinal se reivindica incluso la licitud de la tortura. $^{3}$

Por final, o direito penal do inimigo também está caracterizado no âmbito dos regulamentos do direito penitenciário, quando se constata o endurecimento de condições de classificação dos internos, que têm limitados os benefícios penitenciários, ou ainda, ampliados requisitos para a concessão da liberdade condicional.

Por seu turno, no que se refere ao direito penal do cidadão, o Estado não vê o autor do fato delituoso como um inimigo que deve ser destruído, mas sim como um cidadão que apresentou um comportamento que feriu a norma, ou seja, um deslize reparável. Dessa forma, o indivíduo não perde sua condição de cidadão e seu direito de reintegrar-se à sociedade. Segundo ensinamento de Gracia Martín, citando Jakobs:

El Derecho penal del ciudadano define y sanciona delitos o infracciones de normas que llevan a cabo los individuos de un modo incidental y que son normalmente la simple expresión de un abuso por

${ }^{3}$ GRACIA MARTÍN, Luis. El horizonte del finalismo y el "derecho penal del inimigo". Valencia: Tirant lo Blanch, 2005. p. 106. 
los mismos de las relaciones sociales en que participan desde su status de ciudadanos, es decir, en su condición de sujetos vinculantes a y por el Derecho. El delito de un ciudadano 'no aparece como principio del fin de la comunidad ordenada, sino sólo como irritación de ésta, como desliz reparable', y por ello, conclueJakobs, 'el Estado moderno ve en el autor de un hecho - de nuevo, uso esta palabra poco exacta - normal, $[\ldots]$ no a un enemigo al que ha de destruirse, sino a un ciudadano, una persona que mediante su conducta ha dañado la vigencia de la norma y que por ello es llamado - de modo coactivo, pero en cuanto ciudadano (y no como enemigo) - a equilibrar el daño en la vigencia de la norma'. Esto es así cuando el autor, a pesar de su hecho, ofrece garantías de que se conducirá a grandes rasgos como ciudadanos, es decir, 'como persona que actúa en fidelidad al ordenamiento jurídico'. Por ello, en principio, 'un ordenamiento jurídico debe mantener dentro del Derecho también al criminal', pues éste, por un lado, 'tiene derecho a volver a arreglarse con la sociedad, y para ello debe mantener su status como persona, como ciudadano', y por otro lado, 'tiene el deber de proceder a la reparación, y también los deberes tienen como presupuesto la existencia de personalidad'. ${ }^{4}$

Gunther Jakobs não segue a concepção de Rousseau e de Fitchte. Afirma que, em princípio, um ordenamento jurídico deve manter dentro do Direito o criminoso. Explica que existe uma dupla razão: por um lado, o delinquiente tem direito a voltar a amoldar-se na sociedade, e para isso deve manter seu status como pessoa, como cidadão. Por outro lado, o delinquiente tem o dever de proceder à reparação, e também tais deveres têm como pressuposto a existência de personalidade, ou seja, o delinqüiente não poderia despedir-se arbitrariamente da sociedade em virtude de seu fato.

\footnotetext{
${ }^{4}$ GRACIA MARTÍN, Luis. El horizonte del finalismo y el "derecho penal del inimigo". Valencia: Tirant lo Blanch, 2005. p. 99.
} 
Por outro lado, Silva Sánchez ${ }^{5}$ admite alguma regulação do direito penal do inimigo em determinadas situações extremas e segundo a condição de que aquela resulta sempre o mal menor em termos de proporcionalidade. Portanto, trata de analisar o mal que se causa com o sacrifício de garantias e da liberdade de ação, com o mal a cuja produção tende o perigo que representa o inimigo, que é o que se trata de evitar.

Para Silva Sánchez, o "direito penal do inimigo" e o "direito penal do cidadão" são duas tendências opostas em um contexto jurídico penal. Portanto, é perfeitamente possível que estas tendências se superponham, sejam aquelas que conduzem a tratar o autor como pessoa, sejam aquelas outras dirigidas a tratá-lo como fonte de perigo (ou como meio para intimidar a outros).

Gracia Martin argumenta a respeito da contraposição do direito penal do inimigo e do direito penal do cidadão:

[...] Por esta razón individualiza y distingue a un Derecho penal del enemigo que contrapone al Derecho penal del ciudadano, si bien últimamente quiere relativizar dicha contraposición mediante una presentación del uno y del otro como 'tipos ideales' que difícilmente aparecen en la realidad en estado puro, pues, según él, en el Derecho penal del ciudadano existirían elementos del Derecho penal del enemigo y, viceversa, en éste último también habría elementos del primero. ${ }^{6}$

Vejamos no próximo item mais detalhadamente sobre o Direito penal do inimigo.

\section{DIREITO PENAL DO INIMIGO}

Em maio de 1985, em conferência apresentada no Congresso de Penalistas alemães, celebrado em Frankfurt, Gunther Jakobs utilizou pela

\footnotetext{
${ }^{5}$ SILVA SÁNCHEZ, Jesús María. La expansión del derecho penal: aspectos de la política criminal en las sociedades postindustriales. 2. ed. Madrid: Civitas, 2001. p. 164.

${ }^{6}$ GRACIA MARTÍN, Luis. El horizonte del finalismo y el "derecho penal del inimigo", p. 98.
} 
primeira vez a expressão "Feindstrafrecht" ("direito penal do inimigo"), para denominar um direito oposto ao "direito penal do cidadão". Tal conceito desencadeou nos anos seguintes um grande debate científico e político, tendo em vista que nestes momentos ulteriores Jakobs menciona este conceito não mais com tom de crítica, pois começa a apresentar uma maneira mais aprovadora e legitimadora de sua existência.

Desta forma, em outra Conferência apresentada no Congresso de Berlim, em outubro de 1999, Gunther Jakobs, diferente do seu primeiro trabalho, assume abertamente a necessidade de um "direito penal do inimigo", não como um direito excepcional, mas como outra classe de direito penal inevitável.

Por seu turno, menciona Muñoz Conde:

[...] la necesidad de un derecho penal del enemigo [...] sino como otra clase de Derecho penal, sin duda desagradable, pero inevitable, al que a veces tiene que recurrir la sociedad para el mantenimiento de la seguridad cognitiva frente a los que de un modo permanente se mantienen al margen del sistema social y lo atacan. La característica de este Derecho no sería ya sólo la anticipación de su intervención en hechos alejados de la puesta en peligro de bienes jurídicos, sino también la utilización de penas draconianas, más allá de la idea de proporcionalidad, y la derogación o reducción de algunas de las garantías que concede el Estado de Derecho al imputado en el proceso penal. ${ }^{7}$

Segundo a tese de Gunther Jakobs, em relação a determinados tipos de sujeitos, denominados pelo autor como "inimigos", que de forma permanente, apartam-se dos valores fundamentais da sociedade e se integram em estruturas criminais, deve-se utilizar um Direito penal especial, distinto do Direito penal normal aplicável ao restante dos cidadãos. Para Jakobs, esses sujeitos não podem ser tratados como pessoas com todos

\footnotetext{
${ }^{7}$ MUÑOZ CONDE, Francisco. Comentarios a los Congresos de Trento y Frankfurt sobre el "Derecho Penal del enemigo". Revista Penal, Madrid, n. 18, 1997. p. 336.
} 
seus direitos, e o legislador deve reagir frente a eles com métodos que podem ir mais longe do que permite o Estado de Direito. ${ }^{8}$

Muñoz Conde relata as discussões em redor deste conceito, ocorrida no $30^{\circ}$ Congresso de Advogados penalistas alemães, ocorrido em Hamburgo, no ano de 1977:

Paradójicamente, muchos de los intervinientes en este Grupo de trabajo aceptan esta descripción de Jakobs, precisamente para incluir en ella y denunciar las recientes reformas penales habidas en Alemania en materia de terrorismo, criminalidad organizada, internamiento en custodia de seguridad, utilización de grandes escuchas en el ámbito domiciliario, etc. Pero inmediatamente surgió la cuestión de la legitimidad de un tal Derecho penal del enemigo y de su compatibilidad con el Estado de Derecho. Desde este punto de vista, el profesor friburgués JorgArnold habló de la necesidad de oponer un 'frente de resistencia jurídico' a tales tendencias. Por su parte el también profesor de Derecho penal, Frank Saliger, denunció la ambigüedad de la posición de Jakobs que nada entre lo puramente descriptivo y la legitimidad de su concepto, pero sobre todo la amplitud del mismo, en el que cabe incluir desde la tortura y situaciones como la de los presos de Guantánamo, hasta la prisión preventiva, pasando por cualquier otra norma o práctica que más o menos pueda rozar los límites del Estado de Derecho. ${ }^{9}$

Dessa forma, Muñoz Conde não discorda com Gunther Yakobs da existência de um "Direito penal do inimigo", e suas manifestações mais preocupantes, inclusive em Estados democráticos. Entretanto, diverge, posicionando-se de modo a rechaçar, energicamente, tanto no âmbito político como em qualquer outro âmbito, de modo pleno e total, este denominado "Direito Penal do inimigo".

\footnotetext{
${ }^{8}$ MUÑOZ CONDE, Francisco. Comentarios a los Congresos de Trento y Frankfurt sobre el "Derecho Penal del enemigo". Revista Penal, Madrid, n. 18, 1997. p.340.
}

${ }^{9}$ Ibidem. 
A evolução de Jakobs, desde sua primeira referência ao "Feindstrafrecht" (Direito penal do inimigo) no Congresso de Frankfurt de 1985, até sua intervenção no Congresso de Berlim, em 1999, bem como a evolução legislativa que vem sendo produzida nestes anos em muitos países, demonstram a tendência, cada vez mais evidente, ao "Direito penal do inimigo", inclusive como se apresenta em algumas situações jurídicas, como aos dos presos na Base americana de Guantánamo.

Menciona Muñoz Conde sobre os trabalhos que criticam o Direito penal do inimigo:

En la misma línea crítica se mueve Ulfried Neumann quien además crítica el concepto de Jakobs del enemigo como 'Unperson', es decir, como 'no persona', que supone privarle de derechos que son básicos en el Estado de Derecho y que deben reconocérseles a todo ser humano. Pero sobre todo critica la indeterminación del concepto de 'enemigo', que permite incluir en él a los delincuentes sexuales, a los económicos, a los narcotraficantes, a los terroristas, a los pertenecientes a la 'criminalidad organizada' y, en el fondo, a cualquier disidente, cuando no a simples delincuentes comunes habituales; es decir, a todo el que no viva comúnmente dentro de los patrones más o menos rígidos del sistema social, o lo cuestionen de forma más o menos violenta. ${ }^{10}$

Menciona Faraldo Cabana, que o destinatário deste novo Direito penal não é o cidadão, senão o inimigo, devendo delimitar quem deve receber esta qualificação. O "inimigo", é diferente do "cidadão", que delinqüe ocasionalmente. Ou seja, o inimigo se caracteriza por haver abandonado de forma duradoura e permanente o Direito, seja através de seu comportamento (delinqüentes sexuais perigosos), seja através de sua vinculação a uma organização delitiva (terrorismo, delinquiência organizada), ou através de sua ocupação profissional (delinqüência econômica, delinqüência organizada).

\footnotetext{
${ }^{10}$ MUÑOZ CONDE, Francisco. Comentarios a los Congresos de Trento y Frankfurt sobre el "Derecho Penal del enemigo". Revista Penal, Madrid, 1997. p.346.
} 
Segundo FaraldoCabana:

Esta clase de delincuente no puede pretender ser tratada como persona, puesto que no ofrece a cambio una cierta garantía cognitiva de que se va a comportar como persona, esto es, no garantiza el mínimo de seguridad cognitiva del comportamiento personal, como manifiesta a través de su conducta. Es una no-persona. Aprovecha la desestructuración de una sociedad occidental 'que ha perdido el respaldo tanto de una religión conforme al Estado como de la familia, y en la cual la nacionalidad es entendida como una característica incidental, para construir su identidad al margen del Derecho'. Frente a él la única reacción posible es la inocuización o neutralización, medidas con las que se pretende procurar una especial seguridad cognitiva. En efecto, uno de los efectos producidos por la introducción de este nuevo Derecho penal es el regreso a nociones que, aunque ni mucho menos desconocidas, si habían quedado abandonadas en el discurso penal continental, como la de inocuización. ${ }^{11}$

Na visão de Faraldo Cabana, no âmbito do Direito penal de inimigo incluem-se delitos que negam frontalmente os princípios básicos do modelo de convivência nas sociedades ocidentais, como são os crimes de Estado e aqueles cometidos no âmbito de organizações criminais, incluindo o terrorismo. Portanto, no Direito penal do inimigo, estes delitos apresentariam importantes dificuldades de persecução e prova, de forma que para sua repressão faz-se necessário relativizar as garantias substantivas e processuais.

Deste modo, com penas desmesuradas, como o recurso abusivo ao Direito penal, empregando-o mais além do que lhe resulta permitido, com as restrições e limitações dos direitos e garantias constitucionais, é possível que se possa lutar "eficazmente" contra o inimigo, mas com certeza também está se abrindo uma porta pela qual podem unir-se, sem

${ }^{11}$ FARALDO CABANA, Patricia. Nuevos retos del derecho penal en la era de la globalización.Valencia: Tirant lo Blanch, 2004. p. 316. 
ninguém se dar conta, um Direito penal de cunho autoritário, tão incompatível com o estado de Direito como são as legislações excepcionais das mais brutas ditaduras.

Neste diapasão, afirma Faraldo Cabana:

En esta labor se ha tener en cuenta la necesidad de evitar el peligro de caer en la tentación de la 'perenne emergencia', pues la experiencia demuestra que la creación de una legislación excepcional para una situación que se define como extraordinaria, como sucede con la lucha contra el terrorismo y/o la delincuencia organizada, acaba convirtiendo-se en el modelo de la legislación 'normal', a la que inevitablemente contagia. ${ }^{12}$

Prossegue este autor, que não é somente que o Direito Penal de inimigo seja um Direito penal ilegítimo e ilegitimável, pois ainda que em algum caso possa parecer que seja o mal menor na luta contra graves formas de criminalidade, esta tendência para a expansão supõe um perigo demasiado elevado, precisamente para aquele que diz defender os princípios básicos de convivência social em um Estado que se quer social e democrático de direito.

No próximo item iremos abordar a tortura sob o âmbito do direito penal do inimigo.

\subsection{A tortura como meio legítimo para a obtenção de provas dentro do contexto do direito penal do inimigo}

A verdade que o Direito Penal do inimigo não é algo novo, que está sendo visto pela primeira vez. Basta conhecer o Direito Penal das ditaduras passadas e aquelas ainda existentes em qualquer parte do mundo, para saber até onde se pode chegar o Direito Penal. Atrás desta espécie de Direito Penal pode advir Guantánamo, Abu Chraig, a tortura como meio legítimo de obtenção das provas, as Comissões Militares, a supres-

${ }^{12}$ FARALDO CABANA, Patricia. Nuevos retos del derecho penal en la era de la globalización.Valencia: Tirant lo Blanch, 2004. p. 316. 
são do direito de defesa, e como conseqüência de tudo isto, a pena de morte. Conforme menciona Muñoz Conde:

Naturalmente, eso sólo afectará a los llamados enemigos; para el resto sigue vigente el Estado de Derecho, con todos sus principios y garantías elaboradas por la más refinada Dogmática jurídico penal que conforman el llamando 'Derecho Penal del ciudadano', aplicable a los 'fieles ao Derecho', que alguna vez hayan tenido la tentación de apartarse de él o la mala suerte de caer accidentalmente en sus redes. 13

Para Hassemer: "si se contempla al acusado exclusivamente como a un enemigo se estaría atentando contra la dignidad humana; algo completamente inaceptable" ${ }^{\text {". }}$. Desta forma, adverte o penalista alemão sobre a tendência a uma desmedida proteção em frente ao perigo.

Muñoz Conde referindo-se ao posicionamento de Gunther Jakobs, aduz o seguinte:

Tomemos como ejemplo el mencionado específicamente por el Profesor Jakobs al final de su ponencia: la tortura. Por supuesto que la tortura es en muchos países una amarga realidad y, desde luego, hay pruebas más que evidentes de que se practica o se ha practicado contra presos islamistas en las prisiones de Abu Chraig o de Guantánamo. Por este lado, pues, 'nihil novum sub solo'. Pero de esta realidad no se puede extraer ninguna consecuencia normativa, o por decirlo por una terminología más acorde con la que utiliza el Profesor Jakobs, de la realidad fáctica de la práctica de la tortura no puede deducir-se una norma que la permita o la admita como algo sin duda desagradable, pero inevitable, sino más bien lo contrario: negarle cualquier valor

\footnotetext{
${ }^{13}$ MUÑOZ CONDE, Francisco. Comentarios a los Congresos de Trento y Frankfurt sobre el "Derecho Penal del enemigo". Revista Penal, p.337.

${ }^{14}$ HASSEMER apudMUÑOZ CONDE, Francisco. Comentarios a los Congresos de Trento y Frankfurt sobre el "Derecho Penal del enemigo". Revista Penal, p.344.
} 
normativo a esa realidad fáctica y enfrentarse a la misma 'contra fácticamente', es decir, con la sanción penal de los que han violado las normas, tanto nacionales como internacionales, que prohíben los malos tratos y la tortura, cualquiera que sea la finalidad que pretendan alcanzar los que la practiquen. Lo que el jurista respetuoso con esas normas tiene que hacer es, pues, a mi juicio, denunciar la tortura como un grave delito nacional e internacional lo cometa quien lo cometa, llevar a sus responsables ante los Tribunales nacionales o internacionales y decir que el Estado que justifica o permite estos excesos es un Estado de 'no derecho', igual que lo fueron él régimen nazi o fascista, el franquista $o$ el estalinista, el de los Militares argentinos o el del General Pinochet en Chile, y lo son, lo han sido y lo serán tantos otros, que, de forma más o menos encubierta, utilizan sistemas de represión brutal, contrarios a los derechos humanos y a la sensibilidad humana más elemental, para asegurar sus intereses o sistemas políticos. ${ }^{15}$

Fazendo alusão ao Direito Espanhol, mister salientar que o art. 15 da Constituição Espanhola reconhece o direito à vida e à integridade física e moral, proibindo expressamente a tortura e as penas ou tratamentos desumanos e degradantes. Da mesma forma, a Constituição Brasileira no art. 5, inciso III, determina que ninguém será submetido a tortura nem a tratamento desumano ou degradante.

Os direitos fundamentais têm em sua origem um significado filosófico-político, pois significa o estabelecimento de limites ao poder. A defesa do princípio da dignidade humana e como corolário a proibição da tortura constitui direito fundamental do homem, assegurado nas mais diversas constituições.

Em um Estado social e democrático, o princípio da dignidade é reitor de todas as condutas. Nada pode justificar a desobediência a esse princípio.

\footnotetext{
${ }^{15}$ HASSEMER apudMUÑOZ CONDE, Francisco. Comentarios a los Congresos de Trento y Frankfurt sobre el "Derecho Penal del enemigo". Revista Penal, p.344.
} 
Conceituando o Estado social e democrático, estamos falando daquele que está a serviço de todos os cidadãos, ou seja, não poderá intervir em benefício de determinados grupos. Neste ponto, fica claro que a dignidade é fundamento de um estado social e democrático, porque a dignidade é característica imanente de todo e qualquer homem, ou melhor, não podem ser considerados dignos um grupo de homens em detrimento de outros homens.

O art. 2.2 da convenção da ONU de 1984 dispõe: "Em nenhum caso poderão invocar-se circunstâncias excepcionais, como ameaça ou estado de guerra, instabilidade política interna ou qualquer outra emergência pública, como justificação para a tortura".

Este artigo da convenção consiste em uma inderrogabilidade absoluta da proibição da prática da tortura, seja em qualquer situação, inclusive nas excepcionais (guerra, ameaça, instabilidade política interna ou outro estado de exceção).

Apenas para ilustrar, podemos observar o que passa no Direito Português. O art. 196, nº 6 da Constituição da República Portuguesa estabelece o direito à integridade física, proibindo a prática da tortura. Desta forma as situações de exceção, como o estado de sítio e estado de emergência, apesar de autorizarem a suspensão de alguns direitos, não poderão nunca admitir a existência da tortura.

Resulta óbvio dizer que a tortura consiste em uma afronta à dignidade humana, pois transforma o ser humano em coisa. Nesse diapasão, reflete Grima Lizandra:

La tortura significa una agresión a la dignidad humana. Al torturado se le niega su condición de persona y se le convierte en un objeto. El uso de la tortura significa degradar a la víctima de su condición humana, negarle su libertad, considerarlo 'algo' sometido a leyes puramente mecanicistas: su cuerpo en manos del torturador tiene que reaccionar tal como éste pretende. Esta es la idea que está presente en la mente del torturador y que el torturado percibe y vive en su propia persona: 'tu cuerpo es débil, tan débil que basta que te haga sufrir para que digas y hagas lo que yo quiera: no actuarás conforme a tu voluntad, sino conforme a la mía'. El torturado es considerado por el torturador como un simple 
objeto en sus manos, lo que supone negarle que es un fin en sí mismo (esencia de la dignidad). ${ }^{16}$

Entende-se, desta forma que a tortura questiona a dignidade do torturado como pessoa, sua capacidade e liberdade de decisão, sua integridade física e mental. Enfim, anula sua própria personalidade, negando seu direito de seguir sendo por dentro como a pessoa que é. Como mencionamos anteriormente, na visão de Grima Lizandra, que estamos em perfeita consonância, a tortura ofende a autonomia do indivíduo, cerceando sua liberdade, característica intrínseca da dignidade humana.

Ainda que a tortura indagatória tenha o objetivo do descobrimento da verdade, o torturador apenas admite a resposta que espera, ou seja, a vítima não apenas concede uma informação, mas reconhece o torturador como o dono e possuidor de sua palavra.

Por seu turno, existem situações consideradas como "eficientes", quando através da utilização da tortura, realmente são obtidas informações, que deduzem a verdade. Ainda que seja "eficiente", conforme entendimento de alguns, não pode ser admitida nem pode ser legitimada, nunca e em nenhum lugar. Admiti-la é rechaçar a dignidade da pessoa humana, fundamento para um estado democrático de direito. Ademais, não se pode proteger a legalidade utilizando de meios ilegais, isto é contraditório e extremamente perigoso. A prática da tortura é injusta e cruel.

A liberdade, e, por conseguinte, a autonomia do homem é uma das dimensões da dignidade. A liberdade é a expressão da grandeza do homem. Este é como uma obra de arte, ou seja, é único em sua espécie. Seguindo este raciocínio, a quantidade não significa nada. E uma pessoa não pode ser sacrificada contra sua vontade, ainda que este sacrifício se traduza no bem de muitas outras pessoas, ou quiçá de apenas uma outra pessoa supostamente mais digna. Neste sentido foi ministrada palestra na universidade Pablo de Olavide de Sevilla (Espanha), ocasião em que Roxin, "Catedrático emérito de Derecho Penal de La Universidad de Munich (Alemania)", analisou o fato ocorrido em setembro de 2002, quando foi seqüestrado na Alemanha, o filho de 11 anos de idade de um banqueiro, por um jovem jurista de 28 anos de idade, que exigia determinada quantia em dinheiro pelo resgate.

\footnotetext{
${ }^{16}$ GRIMA LIZANDRA, Vicente. Los delitos de tortura y tratos degradantes por funcionáriospublicos, p. 64 .
} 
Neste seqüestro supracitado, Daschner, vice-presidente da Polícia de Frankfurt, permitiu na manhã de $1^{\circ}$ de outubro que ameaçassem torturar o acusado, se este não indicasse o paradeiro do menino seqüestrado, objetivando salvar a vida da vítima. Contudo, a vítima já havia sido assassinada pelo autor imediatamente depois do seqüestro. Portanto, não era possível o resgate.

Desde que ocorreu esse caso, discute-se na Alemanha se o comportamento do vice-presidente da Polícia foi conforme ao Direito, se Daschner deve ser castigado e se as informações obtidas do acusado mediante a ameaça de tortura podem ser usadas para provar sua culpabilidade.

Segundo Roxin, em conferência ministrada na universidade Pablo de Olavide de Sevilla:

El deber de garantia de la dignidad humana no se puede limitar, ni siquiera mediante una ley que modifique la Constitución. Entre estas regulaciones legales que prohíben la tortura se encuentran numerosos convênios europeus e internacionales con el mismo contenido. ${ }^{17}$

Participamos deste mesmo entendimento da inadmissibilidade de qualquer tipo de limitação ao dever de garantir à dignidade humana.

$\mathrm{O}$ vice-presidente da Polícia, que ordenou a tortura, invocou o dever do Estado de "evitar prejuízos a seus cidadãos". En Frankfurt, Allgemeine Zeitung Brugger declara que em um sequiestro é muito provável que a dignidade da vítima seja menosprezada, apesar de que o seu corpo, sua pessoa, seja utilizado como mero meio para o fim de extorquir. Deste modo, reflexiona Brugger, que em uma situação em que a dignidade enfrenta a dignidade, o ordenamento jurídico pode e deve colocar-se do lado da vítima e exigir do autor a revelação do esconderijo.

Roxin menciona que apesar de considerar convincente, não lhe parece correta a posição de Brugger. Em seu sentir:

\footnotetext{
17 Conferência ministrada por Claus Roxin, "catedrático emérito de Derecho Penal de la Universidad de Munich (Alemania)" realizadanaUniversidade Pablo de Olavide de Sevilla no dia 04 de março de 2004, durante o curso de Doutoradoem "Problemas actuales del Derecho penal y de la Criminologia".
} 
[...] Ciertamente se puede decir que el secuestrador há vulnerado la dignidad humana de la víctima, al igual que hacen muchos delincuentes. Pero esto no legitima al Estado para atacar pos su parte la dignidad humana del autor porque su superioridad moral frente al delincuente reside precisamente en que no utiliza los mismos medios que éste. Si al Estado le está prohibida toda vulneración de la dignidad humana y con ello también la tortura, entonces, lógicamente, no puede existir por su parte una vulneración de la dignidad humana en la omisión de medidas de tortura. Bien es verdad que el Estado está obligado a proteger la vida y la dignidad humana de sus ciudadanos en la medida de lo posible. Pero sólo en la medida de lo posible: la protección puede ser otorgada siempre sólo dentro de los límites establecidos a la actuación del Estado de Derecho. Entro estos límites se encuentra en primer lugar la prohibición de tortura. ${ }^{18}$

Roxin analisa o caso do vice-presidente de polícia de Frankfurt, ressaltando o ponto de vista do policial, ou seja, o conflito de valores jurídicos fundamentais, que são a vida e a dignidade humana. Nesta situação, somente um valor poderia ser protegido, no caso, a conduta foi dirigida a salvar a vida. Para Roxin, o policial tomou o caminho equivocado. Seguindo Roxin, também participamos deste sentir, e apenas para ilustrar, ressaltamos a visão de Kant, ou seja, a de que o homem deve ser tratado sempre como um fim em si mesmo e não somente como um meio para usos quaisquer de esta ou aquela vontade.

Inclusive esse caso alemão foi decidido pela Corte Européia de Direitos Humanos, pois em 2005, o condenado Gäfgen ingressou com ação contra a República Federal da Alemanha na Corte Européia de Direitos Humanos, alegando que sua condenação baseou-se em ameaça de tortura, considerada por ele "a mais massiva violação de Direitos Humanos e da proibição de tortura comprovadamente acontecida na Alemanha do pós-guerra". Neste caso, o tribunal reconheceu que o direito do de-

\footnotetext{
18 Conferência ministrada por Claus Roxin, "catedrático emérito de Derecho Penal de la Universidad de Munich (Alemania)" realizadanaUniversidade Pablo de Olavide de Sevilla no dia 04 de março de 2004, durante o curso de Doutoradoem "Problemas actuales del Derecho penal y de la Criminologia".
} 
ISSN 1983-4225 - v.9, n.2, dez. 2014.

mandante fora efetivamente violado pelo estado alemão: embora não houvesse tortura, as ameaças equivaliam a um "tratamento desumano". Também proclamou que nada, nem o salvamento de vidas, pode justificar a prática da tortura no Direito internacional, ou mesmo alguma violação aos direitos consagrados no art. $6^{\circ}$ parágrafo $3^{\circ}$ da Convenção Européia dos Direitos Humanos. ${ }^{19}$

Seguindo esta linha de pensamento, argumenta Alain Aeschlimann, Chefe da Divisão de Proteção do Comité Internacional da Cruz Vermelha (CICR) :

19 Este interessante caso percorreu a jurisdição alemã, passando pelo crivo internacional na Corte Europeia de Direitos Humanos. Trata-se do caso que ficou conhecido como "DaschnerProzess", que teve lugar entre 2002 e 2004. O estudante de Direito Magnus Gäfgen sequestra o filho de um importante banqueiro de Frankfurt. A polícia acompanha a entrega do resgate, de 1 milhão de euros, e passa a observar os movimentos do sequestrador. Percebendo que, após o resgate, ele não vai ao local do cativeiro e sim reserva uma viagem, a polícia o prende. Naânsia de salvar a vida do jovem sequestrado, o Chefe de Polícia de Frankfurt Wolfgang Daschner, vendo que o sequestrador preso confessa o crime mas se recusa a dizer o local de cativeiro, passa a fazer-lhe ameaças de sofrimentos físicos equiparáveis à tortura. Crendo nas ameaças, Gäfgen indica o local onde se encontra o cadáver, eis que o garoto sequestrado já estava morto. Trata-se de prova absolutamente nula e imprestável por ilícita, segundo a jurisprudência uníssona alemã e dos tribunais internacionais de Direitos Humanos. No entanto, Gäfgen é condenado a prisão perpétua por homicídio qualificado, em 2003. Em 2004 é a vez de o Chefe de Polícia Daschner e seu subordinado serem também condenados, o primeiro pelo crime de "induzir subordinado à prática de crime" e o segundo pelo crime de constrangimento ilegal ("Nötigung"). Em 2005, o condenado Gäfgen ingressa com ação contra a República Federal da Alemanha na Corte Europeia de Direitos Humanos, alegando que sua condenação baseou-se em ameaça de tortura, considerada por ele"a mais massiva violação de Direitos Humanos e da proibição de tortura comprovadamente acontecida na Alemanha do pós-guerra". A ação foi rejeitada. O tribunal reconheceu que o direito do demandante fora efetivamente violado pelo estado alemão: embora não houvesse tortura, as ameaças equivaliam a um "tratamento desumano". Também proclamou que nada, nem o salvamento de vidas pode justificar a prática da tortura no Direito internacional, ou mesmo alguma violação aos direitos consagrados no art. $6^{\circ}$ parágrafo $3^{\circ}$ da Convenção Europeia dos Direitos Humanos. No entanto, considerou a Corte Europeia que a condenação de Gäfgen resultou da prova indiciária e de sua confissão, anteriores à ameaça de tortura, e da materialidade do cadáver encontrado no local que ele indicou. E que a posterior condenação do Chefe de Polícia e seu auxiliar, com explícito reconhecimento pelos tribunais alemães de que seus direitos fundamentais efetivamente foram violados trouxe reparação satisfatória ao demandante que, só por isso, não tinha direito à impunidade ou mesmo à retomada de seu processo. 
Es indudable que los Estados y las autoridades públicas tienen la obligación de adoptar todas las medidas posibles para proteger la seguridad pública. Sin embargo, deben cumplir esa obligación dentro de un marco jurídico que garantice el respeto de la dignidad humana. La detención y el interrogatorio de las personas que pueden proporcionar información sobre posibles amenazas deben ser conformes a esos principios fundamentales del derecho. ${ }^{20}$

Podemos observar que, historicamente, sempre que a tortura é tolerada, o resultado é uma permissividade perigosa, que poderia alargar em demasiado e implicaria em muitos excessos. Mister ressaltar que se tais excessos persistem, ainda que a prática da tortura esteja criminalizada e seja repudiada de uma maneira globalizada (conforme os instrumentos internacionais de combate à tortura), imagine se passamos a aceitar situações excepcionais de admissibilidade da tortura.

Neste diapasão, a legislação internacional é clara quanto ao tema, proibindo o uso de qualquer tipo de tortura e em qualquer situação, estando prevista como cláusula inderrogável no art. 2.2 da Convenção contra a Tortura, art. 4 do Pacto Internacional de Direitos Civis e Políticos, art. 27.2 da Convenção Americana de Direitos Humanos e art. 15.2 da Convenção Européia de Direitos Humanos.

Também entendemos que depois das atrocidades ocorridas durante a segunda guerra mundial, tais instrumentos internacionais devem ser continuamente defendidos e respeitados. Argumenta ainda Alain Aeschlimann, Chefe da Divisão de Proteção do Comitê Internacional da Cruz Vermelha (CICR) :

Sin embargo, las normas acordadas a nivel internacional son mucho más estrictas cuando distinguen lo que es humano y legal de lo que no lo es. El derecho internacional, así como la mayor parte de las legislaciones nacionales, prohíbe comportamientos muy diversos, como los ultrajes contra la dignidad personal, los actos de violencia

\footnotetext{
20 Disponível em:〈http:www.icrc.org/web/spa/sitespa0.nsf/iwplist265> Acesso em: 20 set. 2005.
} 
que atentan contra la vida, la salud y el bienestar, cualquier forma de atentado al pudor, cualquier nivel de brutalidad, los tratos o castigos inhumanos, crueles, humillantes o degradantes, la coerción física o moral, la intimidación, y la mutilación o cualquier otra forma de castigo corporal. ${ }^{21}$

As pessoas que defendem o uso limitado da tortura, aproveitam as preocupações da opinião pública em relação à violência, para justificar a utilização de maus tratos durante os interrogatórios. Em muitas ocasiões ocorridas no Brasil, podemos observar que, diante desta insegurança vivida por todos, a sociedade, de certa forma, urge por uma resposta imediata, que pode significar uma atuação dura da polícia, resultando em "mortes informais" e torturas. A sociedade, muitas vezes, está impregnada do sentimento de vingança. Deseja que o bandido seja efetivamente eliminado da sociedade, seja como for.

É evidente que a tortura não pode constituir a resposta do Estado para o controle da violência. E repetindo as palavras de Roxin: “[...] pero esto no legitima al Estado para atacar por su parte la dignidad humana del autor porque su superioridad moral frente al delincuente reside precisamente en que no utiliza los mismos medios que éste" 22 . E da mesma forma, seguimos argumentando que o Estado não pode proteger a legalidade utilizando de meios ilegais, pois isto seria um contrassenso.

Neste diapasão, compartimos com as opiniões acima aludidas, pois entendemos que o Estado está obrigado a proteger a vida e a dignidade humana de seus cidadãos na medida do possível, dentro dos limites estabelecidos para a atuação de um Estado de direito.

Menciona Tomás y Valiente sobre a eficiência da tortura:

[...] pero como procedimiento para averiguar la verdad, aunque ciertamente falle en muchos casos y pese a que provocará con toda seguridad más confesiones veraces, es innegable que resulta mucho

\footnotetext{
21 Disponível em:〈http:www.icrc.org/web/spa/sitespa0.nsf/iwplist265> Acesso em: 20 set. 2005.

${ }^{22}$ Conferência ministrada por ClausRoxin, "catedrático emérito de Derecho Penal de laUniversidad de Munich (Alemania)" realizadana Universidade Pablo de Olavide de Sevilla no dia 04 de março de 2004.
} 
más eficaz que cualquier rito mágico ordálico. Sobre todo teniendo en cuenta que su eficacia opera en un doble sentido: como medio para descubrir la verdad, y como instrumento para intimidar al torturado y a quienes se sienten potencialmente en su lugar. Si no fuera eficaz la tortura en su doble efecto inquisitivo e intimidativo, no estaríamos aquí y ahora hablando de ella; si no fuese eficaz no sería, como ha sido y tal vez sigue en cierta medida siendo, procedimiento empleado en períodos de fortalecimiento del poder, y en función principalmente de los delitos que hayan podido o puedan poner en cuestión los mecanismos y resortes últimos de ese mismo poder. ${ }^{23}$

Tomás y Valiente argumenta que a tortura é eficaz, não tanto para o descobrimento da verdade, mas como instrumento intimidativo do Estado. Reflete o autor que mesmo que seja eficaz, como podemos conseguir que o Estado opte por renunciar o uso da tortura e aceite cumprir as medidas desta renúncia? Conclui que para que exista esta renúncia, o próprio Estado deve reconhecer que por cima da eficácia repressiva da tortura existem outros valores. É missão do Direito e de todas as pessoas lutarem pelo máximo de respeito aos direitos humanos. Nas palavras de Tomás y Valiente: “[...] No hay nada en la creación más importante ni más valioso que el hombre, que todo hombre, que cualquier hombre" 24 .

Roxin analisa também o debate internacional dos casos das "ticking time bomb situations", ou seja, casos nos quais aquele que coloca uma bomba é detido pela Polícia, mas não quer revelar o esconderijo da bomba, ainda que sua explosão seja iminente e milhões de pessoas estão ameaçadas. Reflete que nesses casos, o autor da tortura está convencido de que sua atuação se dirige a manter o bem jurídico e salvaguardar a vida, elegendo o único caminho eficaz e com grande probabilidade para a sua proteção. E ainda, que se trata de uma situação singular, que provavelmente não voltará a ocorrer. Nesse caso, entende Roxin:

[...] me parece discutible bajo las circunstancias mencionadas, que naturalmente tendrían que ser

\footnotetext{
${ }^{23}$ TOMÁS Y VALIENTE, Francisco. La tortura judicial emEspana. Barcelona: Crítica, 2000. p.209.

${ }^{24}$ Idem. p. 235.
} 
precisadas, todavia, una exclusión de responsabilidad supralegal. Y ello porque la ley tiene que ser dura e inflexible en la determinación de lo justo y lo injusto cuando se trata de una norma fundamental como la prohibición de tortura. Pero en la cuestión de si el autor tiene que ser castigado en casos ético-sociales extremos tampoco es necesario que la justicia tenga corazón de piedra sino que puede ser indulgente, como hace en otras situaciones extremas y de conflicto. ${ }^{25}$

Díaz Pita explica que nos países democráticos que vivenciam uma luta antiterrorista, existem duas caras: uma é a investigação dentro da legalidade, de grupos terroristas e de suas atividades; e a outra é mais sinistra, pois é levada a cabo por membros dos Corpos e Forças de Segurança do Estado, que atuam fora da cobertura legal de um Estado democrático.

Díaz Pita argumenta:

[...] los casos encuentra, as veces, una justificación en virtud de la desestabilización política y las sequelas de muerte, lesiones y daños que los atentados de estos grupos dejan como rastro. Y esta justificación há llegado, incluso, a reflejarse en la amplitud de las exigencias para considerar una conducta como constitutiva de tortura.[...] En efecto no se trata aquí más que de la justificación del uso de la tortura en aquellos países con problemas graves de terrorismo $[\ldots] .{ }^{26}$

Neste diapasão Silva Franco, mencionando Joan Queral Jimenez, fala do quadro sócio-político espanhol, também pertinente em relação à realidade brasileira:

\footnotetext{
${ }^{25}$ Conferência ministrada por Claus Roxin, "catedrático emérito de Derecho Penal de la Universidad de Munich (Alemania)" realizadanaUniversidade Pablo de Olavide de Sevilla no dia 04 de março de 2004.

${ }^{26}$ DÍAZ PITA, Maria del Mar. El bien jurídico protegido en los nuevos delitos de tortura y atentado contra la integridad moral. Estúdios Penales y Criminológicos, Santiago de Compostela, 1997. p. 25-102.
} 
Suele argumentarse que ante la brutalidad de los hechos terroristas, el empleo de métodos expeditivos, aunque prohibidos por la Ley, pueden justificarse. Ello es un craso error por varios motivos. El primero de ellos es que no existe razón que mueva a comportarse como un caballero a quien tortura al presunto terrorista cuando se halla en presencia de otro tipo de delincuente; o dicho de otro modo: la tortura es una práctica progresiva que no conoce límites; hoy puede ser el terrorismo y mañana el tráfico de drogas o siempre el oponente político o el ratero. La segunda razón estriba en la más crasa de las incompetencias profesionales por parte de las autoridades y funcionarios policiales, apoyada por ciertas connivencias en otros sectores, cuanto más violenta y organizada es la delincuencia, tal como ocurre con el terrorismo y otras modalidades de bandolerismo moderno, a respuesta policial tiene que ser más sofisticada y mucho menos visceral. Esperar un comportamiento gentil y cooperativo por parte de un (presunto) delincuente es un soberano dislate. Lo difícil no es saltar la Ley a la tolera - máxime cuando se sabe de básicas complicidades, apoyoso y aplausos -; lo difícil es cumplir con la función de prevención y de averiguación de los hechos punibles siguiendo las pautas de la Ley; y, para eso, en primero lugar, hay que conocer la Ley. ${ }^{27}$

Ainda neste sentir menciona Tamarit Sumalla:

Por sus particulares características la tortura no admite otras causas de exención de responsabilidad criminal que las relativas a la inimputabilidad, aunque una aproximación criminológica a este delito revela que tal posibilidad sería extraña a la realidad cotidiana. La alusión del art. $15 \mathrm{CE}$ a que la tortura se prohíbe 'en cualquier caso' ha sido interpretada como la negación de toda posible justificación o

${ }^{27}$ SILVA FRANCO, Alberto. Tortura. Breves anotações sobre a lei 9.4555/97. Revista Brasileira de Ciências Criminais,São Paulo, n. 19, p. 57, jul./set. 1997.p. 57. 
exculpación basada en el estado de necesidad. Tan tajante prohibición constitucional priva de fundamento a todo intento de contextualizar la tortura (incluso con fines meramente atenuatorios) en la lucha por defender el orden público democrático frente a la subversión terrorista $y$ permite resolver sin ulteriores consideraciones supuestos académicos como la tortura infringida a un terrorista para arrancarle la información sobre el lugar donde ha colocado un artefacto explosivo. Además del carácter intangible de la dignidad humana resulta fundamental en la prohibición incondicional de la tortura la desconfianza hacia la misma como método eficaz para la averiguación de la verdad, lo cual constituye un clásico argumento abolicionista que desempeñó un rol básico en la obra de Beccaria y otros reformadores. En la línea de lo sostenido, el art. 2.2 de la Convención de 1984 establece que 'en ningún caso podrán invocarse circunstancias excepcionales tales como estado de guerra o amenaza de guerra, inestabilidad política interna o cualquier otra emergencia pública como justificación de la tortura. ${ }^{28}$

Depois de tudo que foi esboçado, resulta óbvio dizer que a tortura é inadmissível em qualquer situação, inclusive nas excepcionais. Mister ressaltar que seria muito perigoso admitir a tortura somente para determinadas hipóteses, que são qualificadas de extrema gravidade, como por exemplo, o terrorismo (bomba-relógio). O problema consiste na sua inevitável extensão a outros casos, podendo chegar a converter-se em uma prática sistemática e institucionalizada.

Enfim, neste diapasão, a Convenção contra a tortura e outros tratamentos ou penas cruéis, desumanos ou degradantes, determina no artigo segundo sobre a inadmissibilidade da tortura. Argumenta este dispositivo, e outros instrumentos internacionais citados anteriormente, que em nenhum caso poderão invocar-se circunstâncias excepcionais, como ameaça ou estado de guerra, instabilidade política interna ou qualquer outra emergência pública, como justificação para a tortura. Portanto, a

${ }^{28}$ QUINTERO OLIVARES, Gonzalo. Comentarios al nuevo código penal. Barcelona: Aranzadi, 2000. p. 867. 
Convenção e demais instrumentos internacionais ${ }^{29}$ dispõem expressamente a inderrogabilidade da cláusula de proibição da tortura.

\section{DIREITO PENAL DO CIDADÃO}

Neste item, faremos o estudo do Direito penal do cidadão $0^{30}$, fundamentado na dignidade humana, princípio reitor dos direitos humanos.

${ }^{29}$ A proibição da tortura está prevista como cláusula inderrogável no art. 2.2 da Convenção contra a Tortura, art. 4 do Pacto Internacional de Direitos Civis e Políticos, art. 27.2 da Convenção Americana de Direitos Humanos e art. 15.2 da Convenção Européia de Direitos Humanos.

${ }^{30}$ DALLARI, Dalmo de Abreu. Direitos humanos e cidadania. São Paulo: Moderna, 1998.p.14. A palavra cidadania origina-se da expressão em latim civitas, que quer dizer cidade. De acordo com o ensinamento de Dalmo Dallari: "A cidadania expressa um conjunto de direitos que dá à pessoa a possibilidade de participar ativamente da vida e do governo de seu povo. Quem não tem cidadania está marginalizado ou excluído da vida social e da tomada de decisões, ficando numa posição de inferioridade dentro do grupo social". Fazendo uma reflexão histórica, vale lembrar que a palavra "cidadania"foi usada na Roma antiga para indicar a situação política de uma pessoa e os direitos que essa pessoa tinha ou podia exercer. Desta forma, era realizada a classificação das pessoas para efeito de cidadania. Os estrangeiros e os escravos estavam excluídos da cidadania, e somente uma parte dos cidadãos romanos gozava da cidadania ativa. Apenas o cidadão ativo tinha o direito de ocupar cargos públicos importantes e de participar das decisões políticas, especialmente através do voto.

Segundo ensinamento da Prof Dr $^{\mathrm{a}}$ Maria Garcia, proferido em Banca de Qualificação do Curso de Doutorado da Pontifícia Universidade Católica de São Paulo, ocorrida em 03/05/2011, a expressão "cidadão" denomina o titular de todos os direitos previstos na Constituição. Neste diapasão, afirma Dalmo Dallari: “A cidadania, que no século dezoito teve sentido político, ligando-se ao princípio da igualdade de todos, passou a expressar uma situação jurídica, indicando um conjunto de direitos e de deveres, jurídicos. Na terminologia atual, cidadão é o indivíduo vinculado à ordem jurídica de um Estado. Essa vinculação pode ser determinada pelo local do nascimento ou pela descendência, bem como por outros fatores, dependendo das leis de cada Estado. Assim, por exemplo, o Brasil considera seus cidadãos, como regra geral, as pessoas nascidas em território brasileiro ou que tenham mãe ou pai brasileiro. Essa vinculação significa que o indivíduo terá todos os direitos que a lei assegura aos cidadãos daquele Estado, tendo também o direito de receber a proteção de seu Estado se estiver em território estrangeiro. Desde o começo do século dezenove foi estabelecida a idéia de que direitos específicos da cidadania são aqueles relacionados com o governo e a vida pública. Em primeiro lugar, o direito de votar e ser votado, mas a partir disso existem outros direitos exclusivos dos cidadãos. Entre esses se acha o direito de ser membro do Tribunal do Júri, além do direito de ter um 


\subsection{Direitos Fundamentais e Direitos Humanos}

Existe um estreito nexo de interdependência entre o Estado de Direito e os direitos fundamentais, já que o Estado de Direito exige e implica a garantia dos direitos fundamentais, enquanto que esses exigem e implicam para sua realização o Estado de Direito. Dessa forma, a conceituação dos direitos fundamentais determina a própria significação do poder público, ao existir uma íntima relação entre o papel assinado a tais direitos e o modo de organizar e exercer as funções estatais.

Os direitos fundamentais constituem a principal garantia com que contam os cidadãos de um Estado de Direito de que o sistema jurídico e político em seu conjunto se orientarão frente ao respeito e a promoção da pessoa humana. Desse modo, os direitos fundamentais apresentam-se na normativa constitucional como um conjunto de valores objetivos básicos e como marco de proteção das situações jurídicas subjetivas.

Segundo PerezLuño:

En su significación axiológica objetiva los derechos fundamentales representan el resultado del acuerdo básico de las diferentes fuerzas sociales, logrado a partir de relaciones de tensión y de los consiguientes esfuerzos de cooperación encaminados al logro de metas comunes. Por ello, corresponde a los derechos fundamentales un importante cometido legitimador de las formas constitucionales del Estado de Derecho, ya que constituyen los presupuestos del consenso sobre el que se debe edificar cualquier sociedad democrática; en otros términos, su función es la de sistematizar el contenido axiológico objetivo del ordenamiento democrático al que la mayoría de

cargo, emprego ou função na Administração Pública. Como inovação, foi dado ao cidadão o direito de apresentar projetos de lei, por meio de iniciativa popular, tanto ao Legislativo federal quanto às Assembléias Legislativas dos Estados e as Câmaras Municipais. Foi assegurado também o direito de participar de plebiscito ou referendo, quando forem feitas consultas ao povo brasileiro sobre projetos de lei ou atos do governo. Além disso, foi atribuído também aos cidadãos brasileiros o direito de propor certas ações judiciais, denominadas garantias constitucionais, especialmente previstas para a garantia de direitos fundamentais. Entre essas ações estão a Ação Popular e o Mandado de Segurança, que visam impedir abusos de autoridades em prejuízo de direitos de um cidadão ou de toda a cidadania". 
los ciudadanos prestan su consentimiento y condicionan su deber de obediencia al Derecho. Comportan también la garantía esencial de un proceso político libre y abierto, como elemento informador del funcionamiento de cualquier sociedad pluralista. ${ }^{31}$

Em sua dimensão subjetiva, os direitos fundamentais determinam a tutela da liberdade, autonomia e segurança da pessoa em frente ao poder e aos demais membros do corpo social. Desta forma, no constitucionalismo atual, os direitos fundamentais desempenham uma dupla função: no plano subjetivo seguem atuando como garantias da liberdade individual, acrescentada da defesa de aspectos sociais e coletivos da subjetividade. Por outro lado, no plano objetivo os direitos fundamentais assumiram uma dimensão institucional, a partir da qual seu conteúdo deve funcionalizar-se para a consecução dos fins e valores constitucionalmente proclamados.

Neste sentido, menciona Perez Luño, referindo-se ao Tribunal Constitucional Espanhol:

Nuestro Tribunal constitucional ha sabido captar puntualmente esta nueva situación al aludir al 'doble carácter que tinen los derechos fundamentales. En primer lugar, los derechos fundamentales son derechos subjetivos, derechos de los individuos no sólo en cuanto derechos de los ciudadanos en sentido estricto, sino en cuanto garantizan un status jurídico o la libertad en un ámbito de la existencia. Pero, al propio tiempo, son elementos esenciales de un ordenamiento objetivo de la comunidad nacional, en cuanto ésta se configura como marco de una convivencia humana justa y pacífica, plasmada históricamente en el Estado de Derecho y, más tarde, en el Estado social de Derecho o el Estado social y democrático de Derecho, según la fórmula de

\footnotetext{
31 PEREZ LUÑO, Antonio E. Los derechos fundamentales. 8. ed. Madrid: Tecnos, 2004. p. 21.
} 
nuestra Constitución (art. 1,1). (STC de 14 de julio de 1981, en BJC, 1981, n. 5, p. 331). ${ }^{32}$

Os termos "direitos humanos" e "direitos fundamentais" são utilizados muitas vezes, como sinônimos. Entretanto, a Doutrina busca explicar o respectivo alcance de cada uma das referidas expressões. Desta forma, os direitos fundamentais se designam aos direitos positivados no nível interno, enquanto que a expressão "direitos humanos" seria usada para denominar os direitos naturais positivados nas declarações e convenções internacionais, assim como aquelas exigências básicas relacionadas com a dignidade, liberdade e igualdade da pessoa. ${ }^{33}$

Argumentam Piovesan e Carvalho, fazendo alusão a concepções de outros autores:

Os direitos humanos refletem um construído axiológico, a partir de um espaço simbólico de luta e ação social. No dizer de Joaquín Herrera Flores, compõem uma racionalidade de resistência, na medida em que traduzem processos que abrem e consolidam espaços de luta pela dignidade humana. Invocam uma plataforma emancipatória voltada à proteção da dignidade humana. No mesmo sentido, Celso Lafer, lembrando DanièleLochak, realça que os direitos humanos não traduzem uma história linear, não compõem a história de uma marcha triunfal, nem a história de uma causa perdida de antemão, mas a história de um combate. ${ }^{34}$

Argumenta a autora que o movimento de internacionalização dos direitos humanos surgiu no pós-guerra, como "resposta às atrocidades

\footnotetext{
32 PEREZ LUÑO, Antonio E. Los derechos fundamentales. 8. ed. Madrid: Tecnos, 2004.p. 23.

33 VERGÉS RAMÍREZ, Salvador. Derechos humanos: fundamentación. Madrid: Tecnos, 1997. p.16. Segundo este autor, define os direitos humanos, nos seguintes termos: "Aquellas exigencias que brotan de la propia condición natural de la persona humana, y que, por ende, reclaman su reconocimiento, su respeto e incluso su tutela y promoción por parte de todos; pero especialmente de quienes estén constituidos en autoridad".

${ }^{34}$ PIOVESAN, Flávia; CARVALHO, Luciana PaulaVaz de. Direitos humanos e direito do trabalho. São Paulo: Atlas, 2010.p.5.
} 
e aos horrores cometidos durante o nazismo". Menciona ainda que a barbárie do totalitarismo significou a negação do valor da pessoa humana, e arremata que a Segunda Guerra determinou a ruptura com os direitos humanos, enquanto o Pós-Guerra deveria significar sua reconstrução.

Piovesan acrescenta que na era Hitler, o Estado foi apresentado como o grande violador dos direitos humanos, e aquele período foi marcado pela lógica da destruição e descartabilidade da pessoa humana, resultando no encaminhamento de 18 milhões de pessoas para campos de concentração, com a morte de 11 milhões, sendo 6 milhões de judeus (além de comunistas, homossexuais e ciganos), diante do legado nazista, de condicionar a titularidade de direitos apenas para determinada raça (raça pura ariana). ${ }^{35}$

Ainda tratando da concepção dos direitos humanos, menciona Perez Luño:

Los derechos humanos suelen venir entendidos como un conjunto de faculdades e instituciones que, en cada momento histórico, concretan las exigencias de la dignidad, la libertad y la igualdad humanas, las cuales deben ser reconocidas positivamente por los ordenamientos jurídicos a nivel nacional e internacional. En tanto que con la noción de los derechos fundamentales se tiende a aludir a aquellos derechos humanos garantizados por el ordenamiento jurídico positivo, en la mayor parte de los casos en su normativa constitucional, y que suelen gozar de una tutela reforzada. ${ }^{36}$

Os direitos humanos reúnem em sua significação descritiva aqueles direitos e liberdades reconhecidas nas declarações e convenções internacionais, abarcando também aquelas exigências mais radicalmente vinculadas ao sistema de necessidades humanas, e que deviam ser objeto de positivação, mas não foram. Por seu turno, os direitos fundamentais possuem um sentido mais preciso e estrito, pois descrevem somente o conjunto de direitos e liberdades jurídicas e institucionalmente reconheci-

\footnotetext{
${ }^{35}$ PIOVESAN, Flávia. Código de direito internacional dos direitos humanos anotado. São Paulo: DPJ, 2008. p.5.

${ }^{36}$ PEREZ LUÑO, Antonio E. Los derechos fundamentales. p. 46.
} 
dos e garantidos pelo Direito positivo. Portanto, os direitos fundamentais tratam de direitos delimitados espacial e temporalmente, cuja denominação responde a seu caráter básico ou fundamentador do sistema jurídico político do Estado de Direito.

Piovesan menciona que vem fortalecendo a idéia de que a proteção dos direitos humanos não deve se reduzir ao domínio reservado do Estado, porque revela tema de legítimo interesse internacional. Aduz resumidamente:

Esta concepção inovadora aponta a duas importantes conseqüências: $1^{a}$ ) a revisão da noção tradicional de soberania absoluta do Estado, que passa a sofrer um processo de relativização, na medida em que são admitidas intervenções no plano nacional em prol da proteção dos direitos humanos; isto é, transita-se de uma concepção 'hobbesiana' de soberania centrada no Estado para uma concepção 'kantiana' de soberania centrada na cidadania universal; $2^{\mathrm{a}}$ ) a cristalização da idéia de que o indivíduo deve ter direitos protegidos na esfera internacional, na condição de sujeito de direito. ${ }^{37}$

Deste modo, anuncia-se o fim da era em que o Estado soberano tratava seus nacionais como se fora um problema de jurisdição doméstica. Neste cenário, surge a Declaração universal de 1948, introduzindo a concepção de direitos humanos, marcada pela universalidade e indivisibilidade destes direitos. Conforme explica Flávia Piovesan, "universalidade" porque clama pela extensão universal dos direitos humanos, sob a crença de que a condição de pessoa é o requisito único para a titularidade de direitos, considerando o ser humano como um ser essencialmente moral, dotado de unicidade existencial e dignidade, esta como valor intrínseco à condição humana". E acrescenta que "indivisibilidade porque a garantia dos direitos civis e políticos é condição para a observância dos direitos sociais, econômicos e culturais e vice-versa" ${ }^{38}$.

\footnotetext{
${ }^{37}$ PIOVESAN, Flávia. Código de direito internacional dos direitos humanos anotado, p.9.

${ }^{38}$ Idem. p. 10.
} 
Deste modo, a autora reflete a necessidade de um sistema global em que são adotados tratados internacionais de proteção dos direitos humanos no âmbito da ONU, com amplo alcance, que são monitorados por Comitês instituídos pelos próprios tratados, como órgãos políticos e outros quase judiciais.

Piovesan e Carvalho ao mencionarem sobre os direitos humanos esclarecem que:

Ao final da Segunda Guerra Mundial, emerge a grande crítica e repúdio à idéia de um ordenamento jurídico indiferente a valores éticos, captado pela ótica meramente formal. Intenta-se a reaproximação da ética e do Direito e, nesse esforço, surge a força normativa dos princípios, especialmente, do princípio da dignidade humana. Há um reencontro com o pensamento kantiano, com as idéias de moralidade, dignidade, Direito cosmopolita e paz perpétua. Para Kant, as pessoas e, em geral, qualquer espécie racional devem existir como um fim em si mesmo e jamais como um meio, a ser arbitrariamente usado para este ou aquele propósito. Os objetos têm, por sua vez, um valor condicional, enquanto irracionais, por isso, são chamados "coisas", substituíveis que são por outras equivalentes. Os seres racionais, ao revés, são chamados "pessoas", porque constituem um fim em si mesmo, têm um valor intrínseco absoluto, são insubstituíveis e únicos, não devendo ser tomas meramente como meios. As pessoas são dotadas de dignidade, na medida em que têm um valor intrínseco. Deste modo, ressalta Kant, deve-se tratar a humanidade, na pessoa de cada ser, sempre como um fim mesmo, nunca como um meio. Adiciona Kant que a autonomia é a base da dignidade humana e de qualquer criatura racional. Lembra que a idéia de liberdade é intimamente conectada com a concepção de autonomia, por meio de um princípio 
universal da moralidade, que, idealmente, é o fundamento de todas as ações de seres racionais. ${ }^{39}$

Vejamos minuciosamente no próximo item sobre o princípio da dignidade humana, fonte do sistema protetivo internacional dos direitos humanos.

\subsection{RECONHECIMENTO DA DIGNIDADE HUMANA COMO FUNDAMENTO DA ORDEM POLÍTICA E DA PAZ SOCIAL NA PERSPECTIVADO DIREITO PENAL DO CIDADÃO}

$\mathrm{O}$ alcance da dignidade humana representa a pedra angular do edifício dos direitos humanos, e, por corolário, do direito penal do cidadão. Primeiro, porque tem a função de dar suporte e coesão unitária aos direitos humanos. Segundo, em virtude da conexão interna que apresenta a dignidade com os direitos humanos.

Neste estudo do tema, quiçá vale a pena recordar as palavras de Dela Mata Barranco e Pérez Machío, que reflexionam sobre o conteúdo da dignidade humana e da integridade moral:

La dignidad humana, debe recordarse, se presenta como una síntesis de la totalidad de las dimensiones físicas o espirituales específicas de la persona, que inspira y fundamenta los derechos inviolables inherentes a la misma. Se configura en tal sentido como un principio regulativo que inspira $y$ fundamenta todos y cada uno de los derechos fundamentales, entre los que se encuentra el de la integridad moral, al que su condición como tal le otorga tanto un especial reconocimiento

\footnotetext{
${ }^{39}$ PIOVESAN, Flávia; CARVALHO, Luciana PaulaVaz de. Direitos humanos e direito do trabalho, p. 7.
} 
constitucional como un singular vínculo con la dignidad humana. ${ }^{40}$

Segundo ensinamento de Cerezo Mir:

La referencia a la dignidad de la persona humana es transcendental, pues según filósofos del Derecho de las más diversas orientaciones el respeto a la dignidad de la persona humana es un principio material de justicia de validez a priori. Si el Derecho no quiere ser mera fuerza, mero terror, si quiere obligar a los ciudadanos en su conciencia, ha de respetar la condición del hombre como persona, como ser responsable, como un ser capaz de regir-se por los criterios del sentido, de la verdad y del valor (de lo que tiene sentido o es absurdo, de lo verdadero o de lo falso, de lo que es valioso y de lo que no es). ${ }^{41}$

Acrescenta o penalista espanhol que:

El respeto a la dignidad de la persona humana aparece en la mencionada corriente de la moderna Filosofia del Derecho europeo, como un límite inmanente al Derecho positivo. Se considera, como hacía ya Radbruch, que no hay más Derecho que el Derecho positivo, pero no todo Derecho positivo es Derecho. Hay preceptos que aunque emanen de la autoridad competente y su cumplimiento pueda ser impuesto por la fuerza carecen de obligatoriedad en conciencia, no son Derecho, si suponen una grave

${ }^{40}$ DE LA MATA BARRANCO, Norberto J.; PÉREZ MACHÍO, Ana I.El concepto de trato degradante en el delito contra la integridad moral del art. 173.1 del Código Penal. Revista Penal la Ley, Madrid, n. 15, p. 45-68, 2005. p. 52.

${ }^{41}$ CEREZO MIR, José. Temas fundamentales del derecho penal. Buenos Aires: Rubinzal - Culzoni Editores, 2001.t. I. p. 364. 
infracción del respeto debido a la dignidad de la persona humana. ${ }^{42}$

Atualmente existe uma profunda consciência social universal do respeito à dignidade da pessoa. Conforme observamos no capítulo anterior, este respeito é demonstrado através das diversas legislações nacionais e Declarações Internacionais. Entretanto, segue difícil precisar a conceituação da dignidade, permanecendo de abstrata e difícil apreensão.

De acordo com o Dicionário Aurélio - século XXI, a expressão "dignidade" pode ser conceituada das seguintes formas: a) cargo e antigo tratamento honorífico; b) função, honraria, título ou cargo que confere ao indivíduo uma posição graduada. (ex.: foi elevado à dignidade de reitor); c) autoridade moral, honestidade, honra, respeitabilidade, autoridade (ex.: é pessoa de alta dignidade); d) decência, decoro (ex.: manteve-se em todo o incidente com perfeita dignidade); e) respeito a si mesmo, amorpróprio, brio, pundonor (ex.: empobrecido ao extremo, sabe conservar a dignidade). ${ }^{43}$

A palavra "dignidade" deriva do latim dignitas, que significa virtude, honra consideração. Entende-se, em regra, a qualidade moral que, possuída por uma pessoa, serve de base ao próprio respeito em que é tida. ${ }^{44}$ Por sua vez, a palavra "digno" se origina do latim dignus, que significa honesto, probo, nobre, decente, merecedor, aquele que tem méritos.

No Direito Comparado, podemos mencionar que a Constituição Italiana de 1947 determina em seu artigo 2 que: "La República reconece e garantiza los derechos inviolables del hombre, sea como individuo, sea en las formaciones sociales donde se desenvuelve su personalidad. Y requiere el cumplimiento de los deberes absolutos de solidariedad política, económica y social". Por sua vez, a Constituição Alemã de 1949 determina em seu artigo 1.1 que: "La dignidad del hombre es intangible. Respetarla y protegerla es obligación de todo poder público". No artigo 2.1 esta mesma Constituição declara que: "Todos tienen derecho al libre desenvolvimiento de su personalidad, siempre que no vulneren los derechos de otros, ni atenden al orden constitucional y a la ley moral". A Constituição

\footnotetext{
${ }^{42}$ CEREZO MIR, José. Temas fundamentalesdelderecho penal, t. I. p. 364.

${ }^{43}$ FERREIRA, Aurélio Buarque de Holanda. Novo Aurélio século XXI: o dicionário da língua portuguesa.Rio de Janeiro: Nova Fronteira, 1999.

44 GARCIA, Maria. Limites da ciência: a dignidade da pessoa humana - a ética da responsabilidade. São Paulo: Revista dos Tribunais, 2004.p. 272.
} 
Francesa de 1958 diz que: "El pueblo francés proclama solemnemente su vinculación a los derechos del hombre y a los princípios de la soberania nacional; tal como han sido definidos por la Declaración de 1789, confirmada y completada por el Preámbulo de la Constituición de 1946" 45 . A Constituição Espanhola, no art. 10.1, dispõe: "La dignidad de la persona, los derechos inviolables que le son inherentes, el libre desarrollo de la personalidad, el respeto a la ley y a los derechos de los demás son fundamento del orden político y de la paz social”. E por fim, a Constituição Federal Brasileira de 1988 declara no seu art. $1^{\circ}$, inciso III, que a República Federativa do Brasil "tem como um de seus fundamentos a dignidade da pessoa humana".

A dignidade é um valor intrínseco à condição humana, ou seja, não depende de fatores externos. A dignidade humana reside no fato de que o ser humano é um ser único, insubstituível, dotado de intimidade, inteligência, vontade, liberdade, capacidade de amar e de interagir com os demais. Portanto, algo digno é algo que deve ser sempre respeitado e bem tratado, porque é valioso por si mesmo, e não por sua utilidade para isto ou aquilo.

O reconhecimento da dignidade da pessoa como fundamento do Direito implica em identificar o ser humano com sua condição de pessoa. Desta forma, nos dias de hoje, não existe ser humano que não seja pessoa, como ocorreu nos tempos da escravidão. Tampouco podem existir diferentes classes de pessoa, como acontecia na sociedade feudal. Nesse sentir, argumenta Joaquín Arce y Flórez-Valdés: “[...] la persona, ante el Derecho, há llegado a dar expresión unívoca a una dignidad que no es susceptible de medida ni de variabilidad, toda persona, por serlo, tiene el mismo coeficiente de dignidad"46.

No sentir de Fernández García:

[...] voy a entender la noción de dignidad humana como el valor de cada persona, el respeto mínimo a su condición de ser humano, respeto que impide que su vida o su integridad sea sustituida por otro valor social. Además utilizaré el principio de la dignidad

\footnotetext{
${ }^{45}$ GARRIDO FALLA, Fernando. Comentarios a laconstitución. 3. ed. Madrid: Civitas, 2001. p. 195.

46 ARCE Y FLÓREZ-VADÉS, Joaquín. Los princípios generales del derecho y su
} formulación constitucional. Madrid: Editorial Civitas, 1990. p.147. 
de la persona humana como fuente de los valores de autonomía, seguridad, libertad y igualdad, que son los valores que fundamentan los distintos tipos de derechos humanos. ${ }^{47}$

Montano entende que:

Dignidad es bondad por sí misma, utilidad, bondad para otra cosa. Es la superioridad o elevación en la bondad y, a su vez, la interioridad o profundidad de semejante realeza. Es la suprema valía interior del sujeto que la ostenta. Es una independencia interior. Es aquella excelencia o encubramiento correlativos a un tal grado de interioridad que permite al sujeto manifestarse como autónomo: que se apoya o sustenta en sí mismo. Es sinónimo de majestad y de realeza. ${ }^{48}$

Muguerza afirma:

El ser humano es un sujeto moral, lo que equivale a decir que es un fin en si mismo, y que en esa subjetividad, de la que brotan indisociablemente unidas nuestra autoconciencia y nuestra autodeterminación, es donde, en fin, radica la dignidad humana, esto es, aquello que hace que seamos sujetos y no objetos. Por eso la dignidad personal es la quintaesencia de los derechos humanos: el derecho a ser sujeto de derechos. ${ }^{49}$

47 FERNÁNDEZ GARCIA, Eusebio. Dignidade humana y ciudadanía cosmopolita. Madrid: Dykinson, 2001. p.20.

${ }^{48}$ MONTANO, Pedro J.La dignidad humana como bien jurídico tutelado por el derecho penal.Santiago: UniversitasFriburgensis, 1997.

${ }^{49}$ GRIMA LIZANDRA, Vicente. Los delitos de tortura y tratos degradantes por funcionáriospublicos. Valencia: Tirant lo Blanch, 1998. p. 63. 
Para Díaz Pita ${ }^{50}$ a dignidade humana reside na autonomia moral do indivíduo e na consideração do ser humano como fim em si mesmo ${ }^{51}$. Para Vives Anton "el hombre há de ser tratado en la totalidad de sus relaciones como sujeto y no como objeto; toda instrumentalización del sujeto de derecho implica un ataque a la esencia misma de la dignidad de la persona" 52 . E para Kriele o homem tem que ser considerado sempre e preferivelmente como sujeito, fundamentada sempre na liberdade. Menciona que "en la medida en que es libre, no se le puede imponer necesariamente su destino por las circunstancias externas, sino que él mismo lo configura" 53 .

Essa liberdade fundamenta-se na sua autonomia, pressupõe que somente o homem pode dirigir-se por si mesmo, de acordo com sua própria meta. Montano explica com muita propriedade:

Los animales, más que moverse son movidos. Por ejemplo, en presencia del agua un perro sediento no tiene outra opción que la de calmar su sed. Al contrário el hombre hambriento o sediento, puede decidir, por razones de la más diversa índole, aplazar el momento en que esas pulsiones fisiológicas sean satisfechas. Y como algo similar sucede en las distintas circunstancias que configuran su existencia, cabe afirmar que el hombre goza de un cabal dominio sobre los actos que han de conducirlo a sus distintos objetivos. Encierta forma, essu próprio modelador y creador. ${ }^{54}$

\footnotetext{
${ }^{50}$ DÍAZ PITA, Maria del Mar. El bien jurídico protegido en los nuevos delitos de tortura y atentado contra la integridad moral. Estúdios Penales y Criminológicos, p. 59.Segundo Díaz Pita comentando Garrido Falla "por dignidad humana hay que entender la propia cualidad de ser humano y el respeto a esa cualidad que todos tenemos por el hecho de ser personas. O sea, la superioridad o importancia que se le concede a una persona por el simple hecho de serlo y con independencia de la forma en que se comporte".

${ }^{51}$ GRIMA LIZANDRA, Vicente. Los delitos de tortura y tratos degradantes por funcionáriospublicos, p. 62.

52 Ibidem.

${ }^{53}$ Ibidem.

${ }^{54}$ GRIMA LIZANDRA, Vicente. Los delitos de tortura y tratos degradantes por funcionáriospublicos, p. 62.
} 
Portanto, o homem é digno porque é livre; ou seja, é senhor de suas operações. A liberdade é um índice da inegável grandeza do ser humano. Ademais, o homem é como um diamante ou uma obra de arte, que gozam de valores por se mesmas, porque constituem exemplares únicos em sua espécie. Por isso, a quantidade não conta para nada. Ou seja, a pessoa não pode ser sacrificada contra sua vontade, ainda quando tal sacrifício signifique o bem de muitos, a exemplo do caso da bomba-relógio (terrorismo), em que se cogita a possibilidade de sacrificar um em prol de uma determinada coletividade.

Como menciona Montano: "el ser humano propiamente no tiene un cuerpo, sino que lo es. Su cuerpo goza, participadamente, de la misma dignidad constitutiva que corresponde al alma que es por donde le viene su ser-personal" 55 .

Por fim, o reconhecimento da qualidade de pessoa a todo o ser humano e a consagração da dignidade de todas as pessoas, justifica-se no pensamento de Kant. Ou seja, de que o homem tem um fim próprio, diferentemente de todas as coisas. Desta forma, o homem é um "ser de fins", frente aos seres que lhe rodeia. Ainda neste sentir, argumenta González Pérez: "la dignidad de la persona no es superioridad de um hombre sobre outro, sino de todo hombre sobre los seres que carecen de razón". Neste entendimento, Tomás y Valiente afirma que a dignidade constitui atributo do homem, de todo homem, e de qualquer homem. ${ }^{56}$

Muitas pessoas escreveram a respeito da dignidade, mas certamente Kant é quem marca com maior precisão uma definição do que seja esta tão abstrata expressão.

Kant afirma que: "Aquello que constituye la condición para que algo sea fin en sí mismo, eso no tiene meramente valor relativo o precio, sino un valor interno, esto es dignidad" ${ }^{57}$. Refletindo o imperativo categórico de Kant, entendemos que todo homem, como fim em si mesmo não pode ser utilizado meramente como um meio e tratado como uma coisa. Desta forma, todo homem detém um valor intrínseco, que é a dignidade.

Todo ser racional, ou seja, todo homem possui um valor que não é relativo, que não pode ser substituído por alguma outra coisa equi-

\footnotetext{
${ }^{55}$ MONTANO, Pedro J.La dignidad humana como bien jurídico tutelado por el derecho penal, p. XXII.

56 TOMÁS Y VALIENTE, Francisco. La tortura judicial emEspana, p.148.

${ }^{57}$ GRIMA LIZANDRA, Vicente. Los delitos de tortura y tratos degradantes por funcionários publicos, p.60.
} 
valente. Segundo Kant, a dignidade consiste neste valor. A dignidade não tem preço, porque é superior, não permitindo nenhuma equivalência. ${ }^{58}$

Nas palavras de Kant:

El hombre y, en general todo ser racional, existe como fin en sí mismo, no sólo como medio para usos cualesquiera de esta o aquella voluntad; debe en todas sus acciones, no sólo las dirigidas a sí mismo, sino las dirigidas a los demás seres racionales, ser considerado al mismo tiempo como un fin. ${ }^{59}$

E explicando melhor, Kant continua argumentando:

El valor de todos los objetos que podemos obtener por medio de nuestras acciones es siempre condicionado. Los seres cuya existencia no descansa en nuestra voluntad, sino en la naturaleza, tienen, empero, si son seres irracionales, un valor meramente relativo, como medios, y por eso se llaman cosas; en cambio, los seres racionales llámense personas porque su naturaleza los distingue ya como fines en sí mismos, esto es, como algo que no puede ser usado meramente como medio, y, por

58 ABBAGNANO, Nicola. Dicionário de filosofia. São Paulo: Martins Fontes, 1999.p. 277. Esta interpretação de Nicola Abbagnano ressalta que a dignidade como princípio da dignidade humana é entendida como a exigência anunciada por Kant como segunda fórmula do imperativo categórico: "Age de tal forma que trates a humanidade, tanto na tua pessoa como na pessoa de qualquer outro, sempre também como um fim e nunca unicamente como um meio". Esse imperativo estabelece que todo homem, aliás, todo ser racional, como fim em si mesmo, possui um valor não relativo (como é, por ex., um preço), mas intrínseco, ou seja, a dignidade. Argumenta Abbagnano que o que tem preço pode ser substituído por alguma outra coisa equivalente; o que é superior a qualquer preço, e por isso não permite nenhuma equivalência, tem dignidade. Entende ainda que substancialmente, a dignidade de um ser racional consiste no fato de ele não obedecer a nenhuma lei que não seja também instituída por ele mesmo.

${ }^{59}$ GRIMA LIZANDRA, Vicente. Los delitos de tortura y tratos degradantes por funcionários publicos, p.60. 
tanto, limita en ese sentido todo capricho (y es un objeto del respeto). ${ }^{60}$

Desta forma, argumenta Grima Lizandra:

Tradicionalmente se dice que la dignidad humana es la categoría predicable de todo hombre por el mero hecho de serlo y que, diferenciándolo del resto de seres y objetos del mundo, significa considerarlo libre y con iguales derechos que los demás seres humanos. La dignidad humana supone considerar al hombre libre, en el sentido de capaz de elección, con voluntad de autodeterminación. Y de otro lado, la dignidad humana también exige la igualdad de derechos de todos los hombres, la proclamación de la existencia de una única categoría de hombres. ${ }^{61}$

Neste sentido, entendemos que a dignidade consiste no ponto diferencial. Ou seja, a dignidade humana constitui característica da pessoa humana, diferenciando-a dos demais seres vivos e dos objetos.

Neste raciocínio, refletimos:

[...] debemos partir de Kant, que hace descansar la dignidad sobre dos bases: de um lado, en la consideración de que el hombre es un fin en sí mismo, que no puede ser utilizado meramente como un medio y que no debe ser tratado cual una cosa; y de otro lado, en el reconocimiento de la libertad y autonomía del ser humano. ${ }^{62}$

Assim, participamos do entendimento supracitado de Montando, no sentido de que devemos analisar a dignidade em dois parâmetros: a) o homem é um fim em si mesmo; b) a autonomia é o fundamento da dignidade da natureza humana e de toda natureza racional.

\footnotetext{
${ }^{60}$ Idem. p.61.

${ }^{61}$ Idem. p.59.

${ }^{62}$ MONTANO, Pedro J. La dignidad humana como bien jurídico tutelado por El derecho penal, p. 60 .
} 


\section{CONCLUSÃO}

Enfim, entendemos a dignidade humana não somente como o mais valioso, o que não tem preço, o que exige um respeito imediato, senão também o direito a ter direitos. É neste sentido que também constitui o princípio reitor dos direitos humanos e premissa básica para a construção do Direito penal do cidadão.

Como esclarece De la Mata Barranco e Pérez Machío ${ }^{63}$, a dignidade humana apresenta-se como um princípio regulativo que inspira e fundamenta todos e cada um dos direitos fundamentais, dentre os quais encontra-se a integridade moral, suprimida, em razão da inocuização do indivíduo, ou seja, de sua segregação e isolamento, dentro da proposta do Direito Penal do Inimigo.

Conclui-se, portanto, que a dignidade humana é o fundamento do Direito Penal do Cidadão, ou seja, embasa o entendimento de que apesar do indivíduo ter cometido um erro, ferindo a norma penal, não deve perder sua qualidade de cidadão, e, como tal, pode e deve ser reintegrado à sociedade.

\section{REFERÊNCIAS BIBLIOGRÁFICAS}

MATEU, Juan Carlos Carbonell. Derecho penal: concepto e principiosconstitucionales. 3. ed.Valencia: TirantloBlanch, 1999.

CARVALHO, Salo de. Antimanual de criminologia. 2. ed. Rio de Janeiro: Lumen Juris, 2008.

MIR, José Cerezo. Temas fundamentalesdelderecho penal. Buenos Aires: Rubinzal-Culzoni Editores, 2001.t. I.

HIGHTON, Elena I.; ÁlvAREZ, Gladys S.; GREGORIO, Carlos G. Resolución alternativa de conflictos y sistema penal.Buenos $\mathrm{Ai}$ res: Ad-hoc S.R.L., 1998.

HULSMAN, Louk. Sistema penal y seguridad ciudadana: hacia una alternativa. Barcelona: Ariel, 1984.

${ }^{63}$ DE LA MATA BARRANCO, Norberto J.; PÉREZ MACHÍO, Ana I.El concepto de trato degradante en el delito contra la integridad moral del art. 173.1 del Código Penal. Revista Penal laLey, 2005. 
JAKOBS, Gunther; CANCIO MELIÁ, Manuel. Direito penal do inimigo: noções e críticas. 4. ed. TraduçãoAndré Luís Callegari. Porto Alegre: Livraria do Advogado, 2009.

MESA, María José Rodríguez. Torturas y otros delitos contra la integridad moral cometidos por funcionários públicos. Granada: Comares, 2000.

ROLIM, Marcos et al.Justiça restaurativa - umcaminho para os direitos humanos?Porto Alegre: Ed. Instituto de Acesso à Justiça - IAJ, 2004.Textos para debates.

ROXIN, Claus. Derecho penal: parte general. Tradução para o espanhol de Diego Manuel Luzón Pena. Madri: Civitas, 2003. t. I.

ROXIN, Claus. Fundamentos político-criminales del derecho penal. Buenos Aires: Hammurabi, 2008.

ROXIN, Claus. Problemas básicos del derecho penal. Tradução para o espanhol de Diego Manuel Luzón Peña. Madrid: Reus, 1976.

ROXIN, Claus. Proibição da tortura. O caso DaschnerProzess. Sevilha: Universidade Pablo de Olavide, 04 mar. 2004. (Conferência proferida na Universidade Pablo de Olavide, em Sevilla-Espanha, durante o curso de Doutorado em "Problemas actualesdelDerecho Penal y de la Criminologia").

ROXIN, Claus; ARZT, Gunther; TIEDEMANN, Klaus.Introducción al derecho penal y al derecho penal procesal. Barcelona: Editorial Ariel, 1989. 